E3S Web of Conferences 1, 04002 (2013)

DOI: $10.1051 / \mathrm{e} 3$ sconf $/ 20130104002$

(C) Owned by the authors, published by EDP Sciences, 2013

\title{
Yield, Nitrogen, Phosphorus, Copper and Zinc Uptake by Barley Forage Amended with Anaerobically Digested Cattle Feedlot Manure (ADM)
}

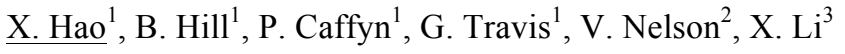 \\ ${ }^{1}$ Agriculture and Agri-Food Canada, Lethbridge Research Centre, Lethbridge AB. T1J 4B1. Canada. \\ Xiying.hao@agr.g.c.ca. \\ ${ }^{2}$ Alberta Agriculture and Rural Development; \\ ${ }^{3} \mathrm{XY}$ Green Carbon Inc.
}

\begin{abstract}
With increasing production of bio-gas and availability of anaerobically digested cattle feedlot manure (ADM), we need a better understanding of the impact of its application on crop production and the environment. The objective of this study was to investigate nutrient and heavy metal uptake by barley forage from soil amended with ADM. A four-year field study was conducted in southern Alberta to compare annual application of ADM liquid (ADML), and the solid fraction separated from the ADM (ADMS) to raw undigested cattle feedlot manure (CFMR). An unamended control (CK) was also included for comparison. Treatments were replicated four times using a split plot experimental design. All amendments were applied in spring each year prior to seeding and barley was grown and harvested at the soft dough stage for making cattle silage feed. All amendments were applied at rates supplying 100 or $200 \mathrm{~kg} \mathrm{~N}$ ha- $1 \mathrm{yr}-1$, assuming $100 \%$ mineral $\mathrm{N}$ and $50 \%$ organic $\mathrm{N}$ was available to crops in the year of application. Averaged over four years, the highest yields were found from ADML (9.55 and 9.6 Mg ha-1 yr-1), and lowest from CK (6.93 Mg ha-1 yr-1), with ADMS and CFMR ( 7.80 to $8.66 \mathrm{Mg}$ ha-1) in between. Contents and total uptake of nutrients and heavy metals $(\mathrm{N}, \mathrm{P}, \mathrm{Cu}$ and $\mathrm{Zn}$ ) by barley forage from ADML were higher than ADMS and CFMR. and higher at $200 \mathrm{~kg} \mathrm{~N}$ ha-1 yr-1 than $100 \mathrm{~kg} \mathrm{~N}$ ha-1yr-1. Our data suggest that anaerobic digestion increases nutrients and heavy metal availability in cattle feedlot manure, but most increases occurred in the liquid fraction. Our data also suggest that the impact of organic amendment application on forage barley production is not only affected by the types of amendment used, but also by agronomic practices (e.g., seeding date) as well as growing conditions.
\end{abstract}

Key words: Heavy metals, field experiment, barley forage production, anaerobically digested cattle feedlot manure.

\section{Introduction}

Bio-gas, mainly methane $\left(\mathrm{CH}_{4}\right)$, production through anaerobic digestion of livestock manure has increased steadily over the years (Pitts, 2010) to meet the increasing demand for renewable energy production and environmental sustainability (Gungor and Karthikeyan, 2005; Holm-Nielson et al., 2009). The anaerobically digested livestock manure (ADM) can be applied to land in its liquid form $\left(\mathrm{ADM}_{\mathrm{L}}\right)$, or separated into liquid and solid fractions (Moller et al., 2006). The liquid fraction can either be used as irrigation water or be recycled back to bio-gas production. The solid fraction $\left(\mathrm{ADM}_{\mathrm{S}}\right)$ can be applied to soil in a similar manner to raw undigested livestock manure. The ADM after $\mathrm{CH}_{4}$ production is rich in nutrients since $\mathrm{CH}_{4}$ production mainly converts carbohydrate to $\mathrm{CH}_{4}$ (Holm-Nielson et al., 2009). Additionally, the physical and biochemical properties could be altered during the anaerobic digestion process, affecting the nutrients and metal behavior and availability in soil after their application. We tested this hypothesis under semi-arid field conditions to determine the nitrogen $(\mathrm{N})$ and phosphorus $(\mathrm{P})$ uptake by barley forage in a Dark Brown Chernozemic clay loam soil amended with $\mathrm{ADM}_{\mathrm{L}}$ and $\mathrm{ADM}_{\mathrm{S}}$ and how they differ from soil amended with raw un-digested cattle feedlot manure $\left(\mathrm{CFM}_{\mathrm{R}}\right)$, 


\section{Materials and Methods}

The study was conducted in semi-arid Southern Alberta, Canada on a Dark Brown Chernozemic soil under no-til barley production from 2008 to 2011. Climate data was downloaded from the Agriculture and Agri-Food Canada Weather Station located about $15 \mathrm{~km}$ from the study site (Table 1).

Three types of amendments and seven treatments were used in this study. Amendments $\mathrm{CFM}_{\mathrm{R}}, \mathrm{ADM}_{\mathrm{L}}$ and $\mathrm{ADM}_{\mathrm{s}}$ were applied at the recommended rate $\left(\mathrm{ADM}_{\mathrm{L} 1}\right.$, $\mathrm{ADM}_{\mathrm{S} 1}$, and $\mathrm{CFM}_{\mathrm{R} 1}$ ) and double the recommended rate $\left(\mathrm{ADM}_{\mathrm{L} 2}, \mathrm{ADM}_{\mathrm{S} 2}\right.$ and $\left.\mathrm{CFM}_{\mathrm{R} 2}\right)$ to meet crop $\mathrm{N}$ needs. The recommended rate is $100 \mathrm{~kg} \mathrm{~N}$ per hectare per year for silage barley production. We assumed $100 \%$ mineral $\mathrm{N}$ (KCl-extractable $\mathrm{NO}_{3}{ }^{-}$and $\mathrm{NH}_{4}{ }^{+}$) and $50 \%$ total $\mathrm{N}$ in the amendment would be available for crop use in the year of applications. An un-amended control (CK) was also included for comparision. All treatments were replicated four times.

Table 1. Weather conditions during study period

\begin{tabular}{l|rrrr}
\hline & $\mathbf{2 0 0 8}$ & $\mathbf{2 0 0 9}$ & $\mathbf{2 0 1 0}$ & $\mathbf{2 0 1 1}$ \\
\hline Growing season $^{\dagger}$ & & & & \\
Evaporation (mm) & 1024 & 1074 & 667 & 892 \\
Precipitation (mm) & 300 & 207 & 163 & 104 \\
Temperature & 16.0 & 16.6 & 15.6 & 17.8 \\
Annual & & & & \\
Evaporation (mm) & 1527 & 1751 & 1567 & 1708 \\
Precipitation (mm) & 522 & 417 & 607 & 541 \\
Temperature & 6.2 & 5.8 & 6.3 & 6.1 \\
\hline
\end{tabular}

†June-Sept. for 2008 and 2009 and July-Sept. for 2010 and 2011; the long-term annual averages for evaporation, precipitation and temperature were $1508 \mathrm{~mm}, 398 \mathrm{~mm}$ and $6.4^{\circ} \mathrm{C}$ and growing season June-Sept. (July-Sept.) averages were $958(758) \mathrm{mm}, 206$ (122) $\mathrm{mm}$ and 16.2 (16.4) ${ }^{\circ} \mathrm{C}$.

Amendments were applied on June 17, 2008, June 4, 2009, June 29, 2010, and July 7, 2011 and barley was seeded the same day or one day after. Barley was harvested as forage for ensiling at the soft dough stage on September 16, 2008, August 29, 2009, Oct 19, 2010, and September 29, 2011. In addition to yield, the forage was analyzed for $\mathrm{N}, \mathrm{P}, \mathrm{Cu}$ and $\mathrm{Zn}$ concentration. The total forage $\mathrm{N}, \mathrm{P}, \mathrm{Cu}$ and $\mathrm{Zn}$ uptakes were estimated based on yield and their concentration. The $\mathrm{N}$ content was determined using a CNS analyzer (Carla Erba, Italy). The $\mathrm{P}$ content was determined by digesting samples with $18 \mathrm{M} \mathrm{H}_{2} \mathrm{SO}_{4}$ following the method of Parkinson and Allen (1975), and the P concentration in the digested solution was determined using an EasyChem Pro discrete analyzer. The $\mathrm{Cu}$, and $\mathrm{Zn}$ contents were determined by digesting a $0.25 \mathrm{~g}$ fine ground sample in a digestion block (Varian, Palo Alto, CA) with $5 \mathrm{~mL}$ of $50 \% \mathrm{HNO}_{3}$ and $2 \mathrm{~mL}$ of $30 \% \mathrm{H}_{2} \mathrm{O}_{2}$ at $85{ }^{\circ} \mathrm{C}$ for $30 \mathrm{~min}$, followed by adding another $2 \mathrm{~mL} \mathrm{H}_{2} \mathrm{O}_{2}$ solution and digesting at $95{ }^{\circ} \mathrm{C}$ for an additional $30 \mathrm{~min}$. The $\mathrm{Cu}$ and $\mathrm{Zn}$ concentrations in the digesting solution were determined using an atomic absorption spectrometer (Varian Model AA240, Palo Alto, CA).

The data were analyzed using the MIXED procedure (SAS Institute Inc. 2008) with treatment, year and their interactions in the model as fixed effects, and replication and replication $\times$ treatment as random effects. Year was treated as a repeated measures effect to account for potential correlations and different variances among years. Various variance-covariance matrices were fitted and the one with the lowest AICC value was used for the final analysis. The UNIVARIATE procedure was used to check the residuals for normality and for potential outliers before performing the final analysis.

\section{Results and Discussion}

\section{Barley forage yield}

Barley forage yield was affected by treatment $(\mathrm{P}=0.002)$ and year $(\mathrm{P}<0.001)$, but not their interaction $(\mathrm{P}=0.154)$. Over the four years, barley forage yields from $\mathrm{ADM}_{\mathrm{L} 1}$ (9.61 Mg ha $\mathrm{yr}^{-1}$ ) and $\mathrm{ADM}_{\mathrm{L} 2}\left(9.55 \mathrm{Mg} \mathrm{ha}^{-1} \mathrm{yr}^{-1}\right)$ were significantly higher than from CK (6.93 $\left.\mathrm{Mg} \mathrm{ha}^{-1} \mathrm{yr}^{-1}\right)$ with yields from the other four treatments in between (7.80 to $\left.8.66 \mathrm{Mg} \mathrm{ha}^{-1} \mathrm{yr}^{-1}\right)$. Averaged across all treatments, 2009 barley yield $\left(11.70 \mathrm{Mg} \mathrm{ha}^{-1}\right)$ was highest, followed by 2008 (9.61 $\left.\mathrm{Mg} \mathrm{ha}^{-1}\right)$, then $2010\left(8.09 \mathrm{Mg} \mathrm{ha}^{-1}\right)$ and 2011 (4.27 $\mathrm{Mg} \mathrm{ha}^{-1}$ ) was the lowest. Applications of organic amendment provided N, P and other macro- and micro-nutrients, thus barley forage yields were higher than the unamended CK. The yields reflected a greater proportion of $\mathrm{N}$ and $\mathrm{P}$ nutrients in available form for $\mathrm{ADM}_{\mathrm{L}}$ than $\mathrm{AMD}_{\mathrm{S}}$ and $\mathrm{CFM}_{\mathrm{R}}$ (data not shown). The highest yield in 2009 was aided by good precipitation and an earlier seeding date, which have been shown to produce better yields in this region. The lowest yield in 2011 was due to a late seeding date, and lack of moisture from low precipitation, high temperatures and high evaporation.

\section{Forage $\mathrm{N}$ content and total uptake}

The forage total $\mathrm{N}$ content was affected by treatment $(\mathrm{P}=0.025)$, year $(\mathrm{P}<0.001)$ and their interaction $(\mathrm{P}=$ $0.002)$. For the first two years, $\mathrm{N}$ contents were similar among all treatments. The $2010 \mathrm{~N}$ content from $\mathrm{ADM}_{\mathrm{L} 1}$ $\left(17.9 \mathrm{~g} \mathrm{~kg}^{-1}\right)$ and $\mathrm{ADM}_{\mathrm{L} 2}\left(18.3 \mathrm{~g} \mathrm{~kg}^{-1}\right)$ was higher than CK $\left(12.6 \mathrm{~g} \mathrm{~kg}^{-1}\right)$ and $\mathrm{ADM}_{\mathrm{s} 1}\left(12.7 \mathrm{~g} \mathrm{~kg}^{-1}\right)$, with values from other treatments in between $\left(14.0-16.6 \mathrm{~g} \mathrm{~kg}^{-1}\right)$. The $2011 \mathrm{~N}$ content from $\mathrm{ADM}_{\mathrm{L} 2}\left(17.5 \mathrm{~g} \mathrm{~kg}^{-1}\right)$ was similar to $\operatorname{ADM}_{\mathrm{L} 1}\left(15.2 \mathrm{~g} \mathrm{~kg}^{-1}\right)$, and $\mathrm{ADM}_{\mathrm{S} 1}\left(12.7 \mathrm{ADM}_{\mathrm{S} 1}\right)$, but higher than $\mathrm{CK}\left(10.5 \mathrm{~g} \mathrm{~kg}^{-1}\right), \mathrm{CFM}_{\mathrm{R} 2}\left(11.8 \mathrm{~g} \mathrm{~kg}^{-1}\right)$, $\operatorname{ADM}_{\mathrm{S} 1}\left(10.7 \mathrm{~g} \mathrm{~kg}^{-1}\right)$ and $\mathrm{ADM}_{\mathrm{S} 2}\left(10.5 \mathrm{~g} \mathrm{~kg}^{-1}\right)$. The $\mathrm{N}$ content decreased over the years for $\mathrm{CK}, \mathrm{CFM}_{\mathrm{R} 1}, \mathrm{CFM}_{\mathrm{R} 2}$, $\mathrm{ADM}_{\mathrm{S} 1}$ and $\mathrm{ADM}_{\mathrm{S} 2}$ treatments but not for $\mathrm{ADM}_{\mathrm{L} 1}$ and $\mathrm{ADM}_{\mathrm{L} 2}$. The lower $\mathrm{N}$ contents from $\mathrm{CK}$ and $\mathrm{ADM}_{\mathrm{S} 1}$ in year 3 and from $\mathrm{CK}, \mathrm{CFM}_{\mathrm{R} 2}, \mathrm{ADM}_{\mathrm{S} 1}$ and $\mathrm{ADM}_{\mathrm{S} 2}$ in year 4 suggest soil $\mathrm{N}$ supply in those treatments might not be sufficient to meet barley forage production needs. This was consistent with decreases in forage $\mathrm{N}$ content over time for those treatments and lower soil available $\mathrm{N}$ 
content at the end than prior to the onset of the experiment (data not shown). For a semi-arid region, the mineralization of organic $\mathrm{N}$ is limited by the lack of moisture and was probably much lower than the $50 \%$ rate we assumed in our study.

Total $\mathrm{N}$ uptake was affected by treatment $(\mathrm{P}<0.001)$ and year $(\mathrm{P}<0.001)$, but not their interaction $(\mathrm{P}=0.287)$. Total $\mathrm{N}$ uptake was highest from the two $\mathrm{ADM}_{\mathrm{L}}$ treatments (155 and $167 \mathrm{~kg} \mathrm{~N} \mathrm{ha}^{-1} \mathrm{yr}^{-1}$ ), and lowest from CK (102 kg N ha $\left.{ }^{-1} \mathrm{yr}^{-1}\right)$, with values (111-128 kg N ha ${ }^{-1}$ $\mathrm{yr}^{-1}$ ) from other treatments in between. The total $\mathrm{N}$ uptake from year one $\left(159 \mathrm{~kg} \mathrm{~N} \mathrm{ha}^{-1} \mathrm{yr}^{-1}\right)$ was similar to year two $\left(176 \mathrm{~kg} \mathrm{~N} \mathrm{ha}^{-1} \mathrm{yr}^{-1}\right)$. Both were higher than year three $\left(125 \mathrm{~kg} \mathrm{~N} \mathrm{ha}^{-1} \mathrm{yr}^{-1}\right)$ with values from year four (55 $\mathrm{kg} \mathrm{N} \mathrm{ha}{ }^{-1} \mathrm{yr}^{-1}$ ) the lowest. The differences in total $\mathrm{N}$ uptake largely reflect the large yield differences, but forage $\mathrm{N}$ contents also contributed to the reduced $\mathrm{N}$ uptake since $\mathrm{N}$ uptake reductions were greater than the yield reductions over the years.

\section{Forage $\mathrm{P}$ content and total uptake}

The $\mathrm{P}$ content was affected by treatment $(\mathrm{P}<0.001)$, year $(\mathrm{P}<0.001)$ and their interaction $(\mathrm{P}<0.001)$. The $\mathrm{P}$ content was generally higher in CFM and lower in $\mathrm{ADM}_{\mathrm{L}}$ and CK treatments for the first two years, with no differences among treatments in year four. The forage barley $\mathrm{P}$ content decreased over the four years for all treatments, except the two $\mathrm{ADM}_{\mathrm{L}}$ treatments, whose $\mathrm{P}$ contents in year three were higher than other years. Similar to N, our forage P data suggests that amendment application rates used in this study were lower than barley forage requirement.

Similar to $\mathrm{N}$, the total $\mathrm{P}$ uptake was affected by treatment $(\mathrm{P}=0.002)$, and year $(\mathrm{P}<0.001)$, but not their interaction $(\mathrm{P}=0.152)$. Total $\mathrm{P}$ uptake was highest from the $\mathrm{CFM}_{\mathrm{R} 2}$ treatment $\left(16.3 \mathrm{~kg} \mathrm{P} \mathrm{ha}^{-1} \mathrm{yr}^{-1}\right)$, and lowest from CK (11.7 kg P ha $\left.\mathrm{yr}^{-1}\right)$, with values (13.9-14.6 kg $\mathrm{P} \mathrm{ha}^{-1} \mathrm{yr}^{-1}$ ) from other treatments in between. The total $\mathrm{P}$ uptake was in the order of year two $\left(20.4 \mathrm{~kg} \mathrm{P} \mathrm{ha}^{-1} \mathrm{yr}^{-1}\right)>$ year one $\left(16.5 \mathrm{~kg} \mathrm{P} \mathrm{ha}^{-1} \mathrm{yr}^{-1}\right)>$ year $3\left(14.2 \mathrm{~kg} \mathrm{P} \mathrm{ha}^{-1}\right.$ $\left.\mathrm{yr}^{-1}\right)>$ year four $\left(5.6 \mathrm{~kg} \mathrm{P} \mathrm{ha}{ }^{-1} \mathrm{yr}^{-1}\right)$. The differences among treatments were much smaller in total $\mathrm{P}$ uptake than in $\mathrm{N}$ uptake. The low $\mathrm{N}$ and $\mathrm{P}$ uptake in year four was mainly due to extremely low forage yield from a late seeding date and unfavorable weather conditions right after seeding. Similar to N, lower P uptake in year four largely reflect the reduced yield, but lower forage $\mathrm{P}$ contents also contributed to the reduced $\mathrm{P}$ uptake since the uptake reductions were greater than the yield reductions.

\section{Forage $\mathrm{Cu}$ content and total uptake}

The $\mathrm{Cu}$ content was affected by treatment $(\mathrm{P}=0.042)$, year $(\mathrm{P}<0.001)$ and their interaction $(\mathrm{P}=0.012)$. The $\mathrm{Cu}$ content from the two $\mathrm{ADM}_{\mathrm{L}}$ treatments was higher than other treatments in years one and two while values were similar among all treatments in years three and four. For most treatments, $\mathrm{Cu}$ contents from years one and two were higher than values from years three and four. The
$\mathrm{Cu}$ levels for year one and two feed (9.2 -16.7 $\left.\mathrm{mg} \mathrm{kg}^{-1}\right)$ were at or above the minimum level $\left(10 \mathrm{mg} \mathrm{kg}^{-1}\right)$ for growing cattle while low levels observed in years three and four (3.8-8.2 $\mathrm{mg} \mathrm{kg}^{-1}$ ) suggest $\mathrm{Cu}$ supplementation would be needed when feeding this forage to cattle.

The total $\mathrm{Cu}$ uptake was affected by treatment $(\mathrm{P}<$ $0.001)$, year $(\mathrm{P}<0.001)$ and their interaction $(\mathrm{P}<0.001)$. Similar to the $\mathrm{Cu}$ content, $\mathrm{Cu}$ uptake was higher from the two $\mathrm{ADM}_{\mathrm{L}}$ than other treatments for the first three years with no differences among treatments in year four. For most treatments, $\mathrm{Cu}$ uptake was also high in years one (77-143 $\mathrm{g} \mathrm{ha}^{-1}$ ) and two (94-248 $\left.\mathrm{g} \mathrm{ha}^{-1}\right)$, decreased in year three (28-62 $\left.\mathrm{g} \mathrm{ha}^{-1}\right)$ and was lowest in year four (28-37). The reduction in $\mathrm{Cu}$ uptake in year four was greater than the reduction in yield. This suggests late seeding not only affected yield, but also decreased $\mathrm{Cu}$ uptake.

\section{Forage $\mathrm{Zn}$ content and total uptake}

The $\mathrm{Zn}$ content was affected by treatment $(\mathrm{P}=$ $0.023)$ and treatment $\times$ year interaction $(P=0.026)$, but not the year $(\mathrm{P}=0.156)$. The $\mathrm{Zn}$ content for $\mathrm{ADM}_{\mathrm{L} 2}$ in year two was higher and $\mathrm{ADM}_{\mathrm{S} 2}$ in year four lower than other treatments. But $\mathrm{Zn}$ contents (14.3-25.5 mg kg-1) observed in our study were all below the minimum levels $\left(30 \mathrm{mg} \mathrm{kg}^{-1}\right)$ to meet cattle needs and lower than values reported for typical barley silage feed $\left(28 \mathrm{mg} \mathrm{kg}^{-1}\right)$.

Total $\mathrm{Zn}$ uptake was affected by treatment $(\mathrm{P}<0.001)$, year $(\mathrm{P}<0.001)$ and their interaction $(\mathrm{P}<0.038)$. Similar to $\mathrm{Cu}$, the $\mathrm{Zn}$ uptake was higher from the two $\mathrm{ADM}_{\mathrm{L}}$ than other treatments For most treatments, the $\mathrm{Zn}$ uptake was also high in years one (135-202 $\left.\mathrm{g} \mathrm{ha}^{-1}\right)$ and two (151-327 $\left.\mathrm{g} \mathrm{ha}^{-1}\right)$, decreased in year three (112-182 $\left.\mathrm{g} \mathrm{ha}^{-1}\right)$ and was lowest in year four $(62-88 \mathrm{~g}$ $\left.\mathrm{ha}^{-1}\right)$. The reduction in $\mathrm{Zn}$ uptake in year four was similar to reduction in yield. This suggests late seeding did not affect the rate of $\mathrm{Zn}$ uptake. The reduction in total uptake mainly reflected reduced yield.

In summary, yield, content and total uptakes of nutrient's and heavy metals $(\mathrm{N}, \mathrm{P}, \mathrm{Cu}$ and $\mathrm{Zn}$ ) by barley forage from $\mathrm{ADM}_{\mathrm{L}}$ were higher that $\mathrm{ADM}_{\mathrm{S}}$ and $\mathrm{CFM}_{\mathrm{R}}$. Our data suggest that anaerobic digestion increases nutrients and heavy metal availability in cattle feedlot manure, but most increases occurred in the liquid fraction. Our data also suggest that the impact of organic amendment application on forage barley production is not only affected by the types of amendment used, but also by agronomic practices (e.g., seeding date) as well as growing conditions.

\section{Acknowledgements}

Funding for this study was provided by Alberta Innovates - Bio Solutions and Agriculture and Agri-Food Canada Matching Investment Initiative (AAFC-MII).

\section{References}

Gungor K, Karthikeyan KG. Probable phosphorus solid phases and their stability in anaerobically digested 
dairy manure. Trans. ASAE 2005; 48:1509-1520.

Holm-Nielsen JB, Al Seadi T, Oleskowicz-Popiel P. The future of anaerobic digestion and biogas utilization. Bioresour. Technol. 2009; 100:5478-5484.

Moller H B, Nielsen AM, Andersen GH, Nakakubo R. Process performance of biogas plants integrating pre-separation of manure. In S.O. Petersen (ed.) $12^{\text {th }}$ Conference of the FAO/ESCORENA Network on Recycling Agricultural, Municipal and Industries Residues in Agriculture (RAMIRAN). Aarhus, Denmark. August 2006; Danish Institute of Agricultural Sciences, Tjele, Denmark.

Parkinson J A, Allen SE. A wet oxidation procedure suitable for the determination of nitrogen and mineral nutrients in biological material. Communications in Soil Science and Plant Analysis $1975 ; 6: 1-11$.

Pitts G. Clean, green and powered by cow patties. The Globe and Mail Industry News. 2010. Available at: http://www.theglobeandmail.com/report-on-busines s/industry-news/energy-and-resources/clean-green-a nd-powered-by-cow-patties/article1471817/ (verified Mar 30, 2012).

SAS Institute Inc. SAS OnlineDoc ${ }^{\circledR}$ 9.2. Cary, NC: SAS Institute Inc. 2008. 